\title{
Japan and Labor Migration: \\ Theoretical and Methodological Implications of Negative Cases
}

International Migration Review, 34(1), 5-32, 2000

(c) 2000 by the Center for Migration Studies, New York All rights reserved

David Bartram

University of Wisconsin-Madison 


\begin{abstract}
Migration scholars have frequently emphasized the tremendous increase in international migration in recent years. But several advanced industrial countries - Japan in particular - have relatively small numbers of foreign workers. Most of the literature on labor migration relates only to "positive" cases, i.e., countries that have actually experienced significant inflows of foreign workers. This paper proposes considering Japan as a "negative case" of labor migration in the post-World War II period. There has been much recent interest in the growing numbers of foreign workers in Japan, but what is most interesting about Japan is the fact that the numbers are relatively small (as a percentage of the labor force) and that they began to increase so late, in comparison to other countries. The main goal of the paper is to advocate consideration of negative cases in migration research; a proper theory of labor migration would distinguish between positive and negative cases.
\end{abstract}




\section{Introduction}

One major goal of theory is to account for variation. Theoretical efforts concerning the causes of international labor migration can do a better job of achieving that goal. Explaining variation has to mean not only understanding why a particular phenomenon occurs in certain times and places, but also understanding why that phenomenon does not appear in other times and places. It would seem that several popular theories of labor migration engage only with the first element of that formulation; in this respect they risk failing to distinguish between what I will refer to as positive and negative cases of labor migration. It may be that existing theories were constructed from consideration only of cases where labor migration has actually occurred. Indeed, there is a widespread perception that migration is a universal feature of human history, and that the incidence of migration is currently increasing rapidly. While this perception is true and useful for some purposes, theoretical advances concerning labor migration may come from taking a different perspective. In particular, this paper argues that migration scholars can benefit from systematic investigation of instances where labor migration has not occurred in large volume. Such instances are usefully conceived as negative cases, especially when existing theory would lead us to expect that migration would have occurred in those instances. Studying negative cases, then, can help advance theory, especially when accounting for variation is the explicit goal (on the more general methodological point, see Moore 1966, Emigh 1997). This paper does not itself offer a new theory; instead, it proposes asking a new type of question.

For such an argument to be meaningful, it has to be shown that significant negative cases in fact exist. The fact that there is little if any labor migration to Egypt, for example, poses no real challenge to existing theory, because such theories would not lead us to expect non-Egyptian 
workers to seek work in Egypt. But there are several wealthier countries where the number of foreign migrant workers is quite small, lower than we would reasonably expect on grounds of existing theory. This paper argues that Japan's experience, and in particular Japan in the late 1960s/early 1970s, is usefully conceived as a negative case of labor migration. The empirical data presented here are intended to support this argument.

The most important observations to make about foreign workers in Japan are that, as a percentage of the labor force, their numbers are small (relative to those in other countries) and that the current flows began relatively late. Even if we include the non-citizen Korean population, foreign labor in Japan constitutes less than 1.5 percent of the Japanese labor force. When we compare Japan to Western European and other advanced countries, where the foreign share of the labor force has at times exceeded ten percent (in the mini-states of Luxembourg and Liechtenstein the figures exceed forty percent), what emerges is that Japan still stands out as a minor user of foreign labor. Moreover, the current influx that has attracted so much attention began only in the mid-1980s - long after Japan became an economic powerhouse with very high growth rates and high standards of living. On these grounds, I offer the following assertion (which I will defend further as the paper progresses): Japan in the post-World War II period has not been a significant host country for foreign labor, and it does not belong in the same category as other countries that have long used imported workers, such as Germany and France. ${ }^{1}$

International migration scholars are well aware that the number of foreign workers in Japan is small. But even those who begin by noting this fact usually go on to ask and answer the following question: why are there foreign workers in Japan? Given that the numbers in Japan have been increasing, this approach is understandable: we want to understand an emerging trend. 
It is, however, the wrong question, or at least not the most interesting one. The real question is, why are the numbers so small, and why have they remained small for so long? This paper addresses this question specifically in relation to Japan's experience of labor shortages from 1967 until 1974 (when the oil crisis and the world-wide recession dramatically reduced the demand for labor), but many of the points I make are in principle applicable to later periods as well.

\section{Japan in the Labor Migration Literature}

The main empirical focus of this paper is Japan's non-use of foreign labor under tight labor market conditions in the late 1960s and early 1970s. Analysis of questions concerning labor migration to Japan during this period is relatively scarce. ${ }^{2}$ This lack of discussion quite possibly derives from the fact that scholars are not accustomed to thinking about labor migration in terms of negative cases; indeed, it takes a conceptual shift to begin asking questions concerning something that did not happen (c.f. Hammar and Tamas 1997). The main goal of this paper is to argue that explaining variation in migration outcomes requires us to do so.

Most scholars who have paid attention to this period tend to downplay its importance to the question of foreign labor in Japan. Usually, the analysis points out that surplus Japanese rural workers moved into the urban industrial sector, obviating any "need" to import labor (e.g. Lie 1997, Sellek and Weiner 1992, Sellek 1994, Cornelius 1994). Reubens (1981) also emphasizes this point, though he discusses as well other factors that allowed Japan to refrain from importing labor, such as the fact that low-level work is not stigmatized in Japan the way it is in most Western countries. It is thus said to be easier to attract native workers to what in many other 
societies would be considered undesirable work. The implication of this domestic labor reserve thesis is that there was no real need for foreign labor at this time, and therefore that the question of foreign labor is not worth pursuing further. Alternatively, Japan's insular culture is said to have inhibited the government from acceding to employers' demands for imported labor (Martin 1991, Zolberg 1981; see also below).

Mori's analysis (1997) is more detailed: in addition to discussing the central role of domestic labor reserves, Mori presents data concerning wage differentials and labor shortages according to firm size. He describes the increasing labor market mismatch caused by the persistence of unattractive jobs in the face of increasing educational attainment. On balance, however, this analysis perhaps raises more questions than it answers: “...the existing labor force was more fully employed in the 1960s and early 1970s. One should take note here that the use of foreign labor emerged in response to the comparatively less tight labor market of the recent [late 1980s] expansion" (1997: 40). Mori does not sufficiently explore the implications of this essential point, which is based on the fact that the "openings to applicants" ratio was higher in the early 1970s than in the late 1980s (see below). The central thrust of the argument, however, is the one introduced above: employers in the earlier period were able to find other solutions to labor shortages (primarily drawing on rural Japanese workers), while more recently they have had no choice but to turn to foreign labor because those reserves have been drawn down.

Again, however, the question of labor migration (or its absence) to Japan during this period has received relatively little attention. Some of those who discuss the later entry of foreign workers into Japan do not treat the earlier period at all (see e.g. Nagayama 1992, 1996, Shimada 1994, Sassen 1993, Foote 1993, Okunishi 1996). Certain kinds of research concerning 
labor migration to Japan may not require extensive historical background. But addressing the theoretical question of what causes labor migration to a country such as Japan would seem to necessitate serious engagement with the question of why Japan did not import workers in an earlier period of tight labor markets.

While Japan's experience with foreign labor was minimal prior to the 1973 recession, more recently stocks of foreign workers have begun to increase. This increase has led some observers to conclude that Japan can and should be analyzed in much the same terms as other labor importing countries (e.g. Yamanaka 1993, 1994). Others have addressed both the recent influx and the fact that the numbers remain small relative to many other countries (Mori 1997, Mahmood 1996, Oka 1994, Shimada 1994). The particular explanations offered are not at issue here: instead, what is relevant is the way the problem is conceptualized. While the main focus of this paper is Japan's earlier engagement with the question of foreign labor, it would seem that even in the recent period the notion of negative cases is useful for analyzing Japan. Given that foreign workers currently constitute between approximately $1.2 \%$ of the Japanese labor force, the tremendous attention this influx has received seems a bit out of proportion. Even sophisticated treatments of the topic sometimes use exaggerated language: Mori speaks of their numbers having "increased dramatically" (1997: xi), Iguchi refers to "an enormous influx of foreign labor" (1998: 300), and Komai describes the introduction of the trainee system as "epochmaking" insofar as it opened the door for the "large-scale employment" of foreign labor (1995: 47-48). This type of description is consistent with a more general assumption that what needs explaining is the presence and mode of insertion of foreign labor in Japan. Such analyses are valuable on their own terms. But understanding Japan's implications for theories of labor 
migration requires first asking: what is this phenomenon a case of? In other words, what do we "see" when we look at foreign labor in Japan? Even in the more recent period, then, it may be more useful to "see" only a rather insignificant influx of foreign workers, or what I am calling a negative case.

Concerning the more recent period, however, these are merely tentative suggestions. The focus of this paper is Japan's attempt to grapple with the issue of foreign labor in the late 1960s and early 1970s. The next section begins our empirical discussion of this earlier period.

\section{Before the Oil Shock - Was Japan Different?}

The question of Japan's limited use of foreign labor becomes especially compelling when we focus on one of Japan's most extraordinary periods of high growth rates, i.e., the late 1960s and early 1970s (the so-called Izanagi boom). This was the period in which significant labor shortages first became apparent. It was also perhaps the first time in the post-war period in which the Japanese government considered, but mostly rejected, the idea of importing labor from abroad (Evans 1971, Utsumi 1988, Sellek 1994). This period seemed to combine the elements that had led other countries to turn to imported labor to resolve shortages. Japan in the pre-oilshock years, then, might stand as a major anomaly relative to the tendency in many advanced industrial countries to import foreign labor. The proportion of foreign labor in the Japanese labor force remained well below one percent, while in many other industrial countries the percentage rose to a much higher level (see Table 1). Moreover, most foreign workers in Japan were longterm Korean residents who had entered the country prior to World War Two. They have long 
held jobs with lower status and lower pay, and this fact is no doubt related to social discrimination as well as to their distinct legal status as noncitizens: they were not eligible to work as civil servants and were long barred from professions such as teaching, for example (Hicks 1997). On the other hand, they were never "temporary" guestworkers of the classical European type.

But was Japan in the 1960s and 1970s really in the same situation as other industrial countries? Again, many analysts of this period (e.g. Reubens 1981, Sellek 1992, Boltho 1975, Nakamura 1991, Galenson and Odaka 1976) point out that one of the reasons Japan did not import workers was that it had another alternative: Japanese workers from rural areas. Perhaps a country that could draw on its own citizens for labor cannot really be said to have experienced a labor shortage. In addition, perhaps Japan was quite different from other countries in other respects as well, e.g. economic growth rates, unemployment rates, inflation rates, etc. - all of which could have helped determine whether Japan "really needed" foreign labor. We need to consider these issues seriously before designating pre-oil-shock Japan as an anomaly concerning foreign labor. In this section I therefore present and analyze data to highlight the similarities and contrasts between Japan and some other advanced industrial countries, especially regarding the labor force.

From Table 2, we see that Japan indeed had a substantially higher proportion of its labor force employed in agriculture in 1960, around the time when some European countries began importing labor. For any given year through 1970, Japan's proportion in agriculture was more than twice that of Germany, for instance. 
Table 1: \% Foreign Workers in Labor Force

$\begin{array}{ccccc} & \text { Japan } & \text { W. Germany } & \text { France } & \text { Sweden } \\ 1960 & 0.3^{\mathrm{a}} & 1.5^{\mathrm{b}} & 4.9^{\mathrm{c}} & 3.3^{\mathrm{c}} \\ 1964 & 0.3^{\mathrm{a}} & 4.4^{\mathrm{b}} & 6.2^{\mathrm{d}} & 4.2^{\mathrm{d}} \\ 1969 & 0.3^{\mathrm{a}} & 7.3 & 6.1^{\mathrm{c}} & 5.6^{\mathrm{c}} \\ 1974 & 0.3^{\mathrm{a}} & 8.2 & 7.1^{\mathrm{c}} & 4.9 \\ 1979 & 0.3^{\mathrm{a}} & 7.6 & 6.2 & 5.2 \\ 1984 & 0.3^{\mathrm{a}} & 6.5 & 6.9 & 5.0 \\ 1988 & 0.8^{\mathrm{e}} & 6.6 & 6.3 & 5.0 \\ 1992 & 1.2^{\mathrm{e}} & 6.1 & 6.0 & 5.3\end{array}$

Computed from the following sources: The denominator (total labor force) is from $O E C D$ Economic Outlook; the numerator (foreign workers) is from OECD-SOPEMI, unless otherwise noted: 'ajapan Ministry of Justice Study Group on Immigration Statistics 1990; ${ }^{\mathrm{b}}$ Herbert 1990; ${ }^{\mathrm{c}}$ Böhning 1984; ${ }^{\mathrm{d}}$ Descloitres 1967; ${ }^{\mathrm{e}}$ Mori 1997 and Japan Ministry of Justice Study Group on Immigration Statistics 1990.

Table 2: \% of Labor Force in Agriculture

$\begin{array}{lcccc} & \text { Japan } & \text { France } & \text { Germany } & \text { Sweden } \\ 1960 & 29.7 & 22.1 & 13.8 & \\ 1961 & 28.6 & 21.4 & 13.0 & \\ 1965 & 23.3 & 17.5 & 10.8 & 11.2 \\ 1969 & 18.6 & 14.8 & 9.2 & 8.4 \\ 1970 & 17.2 & 14.0 & 8.6 & 8.0 \\ 1975 & 12.4 & 9.9 & 6.6 & 6.3 \\ 1980 & 10.2 & 8.1 & 5.1 & 5.5 \\ 1985 & 8.5 & 6.8 & 4.2 & 4.7 \\ 1990 & 7.1 & 5.2 & 3.3 & 3.4\end{array}$

Source: OECD Labor Force Statistics

However, we should not compare Japan to other countries in the same years: other countries experienced labor shortages in earlier years and thus had to confront problems of labor supply earlier. West Germany and France started importing workers in the 1950s. By 1961, West Germany had signed recruitment agreements with Italy, Spain, Greece and Turkey, and the 
inflow of labor had begun in earnest. France had signed recruitment agreements even earlier. Japanese employers began to complain of sustained labor shortages only in the late 1960s. The proper comparison, then, is between Japan in the late 1960s and France and Germany in the early 1960s.

The proportion of the Japanese labor force employed in agriculture in 1969 (18.6\%) is indeed higher - though not outrageously - than the comparable figure for West Germany in 1961 (13\%), but it is lower than the French figure for 1961 (21.4\%) (Table 2). In other words, the "reserves" of French workers employed in agriculture were proportionately greater than those of Japan, at the time each country confronted the problem of insufficient labor supply - but this fact did not keep the French government from sanctioning the recruitment of foreign workers. The fact that Japan could draw on reserves from agriculture was without question one of the factors that enabled the country to avoid importing labor. But the mere availability of surplus agricultural workers does not explain why Japan actually adopted this particular solution for alleviating labor shortages.

It may be, however, that Japan had other reserves of labor as well, so that it was not as difficult to tap other domestic supplies of labor as in other countries; in this case the question of foreign labor would not have been as relevant to Japan at this time. Possible candidates might include women not in the labor force, men not in the labor force, and unemployed persons. The data, however, show that Japan had fewer such persons to draw on than other countries. Overall labor force participation rates (Table 3) were higher in Japan in 1969 (65.6\%) than in France (55.7\%) or West Germany $(60.1 \%)$ in 1961 - in the case of France, significantly higher. Female labor force participation rates (Table 4) as well were much higher in Japan than in other 
countries: 50.1\% in Japan vs. $41.5 \%$ in West Germany (again, 1969 vs. 1961). (If data were available for France in the early 1960s, they would likely show an even greater difference, by extrapolation.) Japanese female labor force participation rates were even higher than those for Sweden throughout the 1960s, though the Swedish rate surpassed the Japanese rate in 1971. Unemployment rates (Table 5) for all countries in the 1960s reveal that there were very few people looking for work who did not find it: Japan's rate was only marginally higher than West Germany's throughout this period. On these measures, then, France, West Germany, and Sweden had more candidates in the domestic population for activation into the labor force than Japan - yet the former countries turned to foreign labor while Japan did not.

Table 3: Total Labor Force Participation (\%)

$\begin{array}{lcccc} & \text { Japan } & \text { France } & \text { Germany } & \text { Sweden } \\ 1960 & 69.2 & 56.3 & 60.1 & \\ 1961 & 69.1 & 55.7 & 60.1 & \\ 1965 & 65.8 & 54.6 & 58.5 & 61.2 \\ 1969 & 65.6 & 54.1 & 65.6 & 61.2 \\ 1970 & 65.3 & 54.3 & 56.5 & 61.5 \\ 1975 & 63.1 & 54.3 & 54.9 & 63.6 \\ 1980 & 63.3 & 54.5 & 54.4 & 64.6 \\ 1985 & 63.0 & 53.6 & 54.8 & 64.7 \\ 1990 & 63.3 & 53.6 & 55.7 & 64.5\end{array}$

Source: OECD Labor Force Statistics 
Table 4: Female Labor Force Participation (\%)

$\begin{array}{lcccc} & \text { Japan } & \text { France } & \text { Germany } & \text { Sweden } \\ 1960 & 54.5 & & 41.8 & \\ 1961 & 54.3 & & 41.5 & \\ 1965 & 50.7 & & 40.4 & 44.7 \\ 1969 & 50.1 & 37.1 & 38.7 & 47.0 \\ 1970 & 49.8 & 37.6 & 38.7 & 48.1 \\ 1975 & 45.8 & 40.3 & 39.8 & 53.3 \\ 1980 & 47.6 & 42.9 & 40.7 & 57.4 \\ 1985 & 48.7 & 44.1 & 41.4 & 59.7 \\ 1990 & 50.1 & 45.7 & 44.3 & 60.5\end{array}$

Source: OECD Labor Force Statistics

Table 5: Unemployment (\%)

$\begin{array}{ccccc} & \text { Japan } & \text { France } & \text { Germany } & \text { Sweden } \\ 1960 & 1.7 & 1.3 & 1.0 & \\ 1961 & 1.4 & 1.1 & 0.7 & \\ 1965 & 1.2 & 1.4 & 0.6 & 1.2 \\ 1969 & 1.1 & 1.7 & 0.7 & 1.9 \\ 1970 & 1.1 & 1.7 & 0.6 & 1.5 \\ 1975 & 1.9 & 4.1 & 4.0 & 1.6 \\ 1980 & 2.0 & 6.2 & 3.2 & 2.0 \\ 1985 & 2.6 & 10.5 & 8.2 & 2.8 \\ 1990 & 2.1 & 9.1 & 6.3 & 1.7\end{array}$

Source: OECD Labor Force Statistics

There is of course a difference between transferring labor from one economic sector to another and pulling inactive people into the labor force. The former are already active, while many of the latter are probably inactive for a reason and might well resist efforts to mobilize them. One of the most common ways of explaining the labor migration "problem" is to point out that there are jobs citizens are simply unwilling to do: citizens and foreign workers are said to be complementary, not competitive. But while it may seem unlikely that non-participating citizen 
women (for example) are good potential substitutes for foreign workers, the Swedish government in the late 1960s deliberately tried to decrease the need for foreign labor by encouraging more women to enter the labor force. "Encouragement" meant not exhortation but policy changes, including expanded community provision of child care and tax policy changes that penalized single-earner households (Cook 1978). The West German government, on the other hand, chose a different path: supporting "traditional family" roles for women and refraining from policies that would have facilitated working on the part of mothers (Kamerman 1979). The share of foreigners in the West German labor force rose to a rather higher level than in the Swedish labor force (9.8\% in 1973 for Germany, 5.7\% in 1976 for Sweden - see Table 1). Female labor force participation was certainly not the only factor accounting for the difference, but it seems unlikely that raising participation rates (in West Germany, for example) would have had no effect whatsoever on the demand for foreign labor. Japan arguably had fewer possibilities for this option, given that its female (and overall) participation rates were already higher than those of the other countries described here.

Another potential way to intensify the use of Japanese labor was to draw on the very large self-employed population: Galenson and Odaka (1976) note that the proportion of wage and salaried workers was much lower in Japan than in many western European countries. This point leads to a further discussion of the fact that France imported labor despite the fact that there were very large numbers of agricultural workers that might have substituted for foreigners. The reason this potential was not exploited to any great extent was that the French government had a longstanding policy of supporting the agricultural sector, with an explicit view to keeping peasant agriculture viable in the face of strong competitive pressures from other countries. (Japan and 
France are rather similar in this respect.) The same point holds with regard to small business in Japan (as well as to the low rate of female labor force participation in Germany): there are very large numbers of self-employed workers in Japan in large part because government policies create the conditions for them to survive, to a degree that does not characterize other advanced industrial countries. In other words, the Japanese government made it possible for many selfemployed workers to refrain from engaging in wage labor, a point illustrated by the fact that the self-employed population is still quite large relative to other advanced capitalist countries. In both countries, there is a politics of labor supply that helps determine to what extent workers will move into urban wage labor when demand for such labor increases.

In many of the discussions concerning labor shortages in Japan, the basic argument is that there were labor reserves sufficient to meet the demand, at least in the long run. I have not tried to argue here that there were not reserves. Rather, I have defended two points: First, the reserves were not obviously of a different order of magnitude from those of other countries that did import labor. And secondly, and partly as a consequence, the availability of labor reserves among the domestic population does not suffice to explain why they were in fact used. When analysts of Japan claim that the reason Japan did not import labor is that the country had labor reserves, they are implicitly claiming that there is a "tipping point" of some sort: when labor reserves "run out", a country needs foreign labor, and Japan still had not reached that point in this period. I do not argue in this section that such an argument merely puts the "tipping point" in the wrong quantitative place; instead, I have presented data to show that the concept itself is problematic as an explanation for the absence of labor migration (and, therefore, for the presence of foreign workers in other countries as well). 
Another potential objection to the argument that Japan was in a situation substantially similar to that of other countries experiencing labor shortages might be that the Japanese economy was less developed and therefore had less of a "structural" need for foreign labor. Again, however, the (admittedly crude) data do not support this objection. In constant terms (1990 prices, 1990 exchange rates), the Japanese per capita GDP in 1969 was higher than the French or German figures for 1961: US\$11,135 vs. US\$9,165 and US\$9,248. In addition, economic growth rates, expressed as increases in per capita GDP (Table 6), show that the Japanese economy was expanding substantially faster than the other economies, perhaps indicating that the Japanese demand for labor was expanding faster as well.

Table 6: Percent Increase, per capita gross domestic product (annual averages)

$\begin{array}{ccccc}1960-64 & \text { Japan } & \text { France } & \text { Germany } & \begin{array}{c}\text { Sweden } \\ 4.5\end{array} \\ 1965-69 & 10.3 & 3.5 & 4.5 & 3.3 \\ 1970-74 & 3.0 & 1.9 & 2.6 & 2.2 \\ 1975-79 & 3.6 & 3.4 & 2.7 & 1.1 \\ 1980-84 & 3.2 & 2.1 & 1.0 & 1.6 \\ 1985-89 & 4.2 & 2.5 & 2.5 & 1.8\end{array}$

\section{Source: Statistics OECD}

In sum, then, if we compare Japan to other countries for the relevant years, we see that: the Japanese economy was growing more rapidly and was at a level of development comparable to other, labor importing countries; the proportion of Japanese workers employed in agriculture was well within the range of other countries; and labor force participation, both overall and female, was higher than that of other countries that had already imported significant numbers of 
foreign workers. Thus the argument that Japan refrained from bringing labor from abroad because it had domestic labor reserves is at best incomplete and at worst does not stand up at all to comparative investigation. Japan did resolve labor shortages in this period partly by drawing on reserves of labor; but given that other countries might have done the same but did not, the real issue then becomes explaining why and how Japan followed this path. On these grounds Japan stands as a significant anomaly, having avoided importing labor through the high growth years of the late 1960s and early 1970s despite labor shortages that were arguably at least as severe as those experienced earlier by labor-importing countries. Japan is thus usefully conceived as a negative case of labor migration.

\section{Official and Private Perceptions of the Problem}

Even though Japan did have a sizable agricultural labor force that would eventually be transferred to other sectors, this transition took place too slowly to satisfy the needs of many employers, partly because many of those working in agriculture were rather older and not inclined to take urban jobs (Dore 1986). There was a prolonged period in which the available labor force was simply insufficient to meet demand. The active openings-to-applicants ratio was quite high for a number of years and in fact was higher during this period than in the late 1980s, when the number of foreign workers in Japan started to increase significantly (Table 7). Analyses of Japan in the early 1970s (e.g. Reubens 1981, Mori 1997) usually read as if the labor shortage were a single event that was resolved with a single-stroke solution: Japan had a labor shortage during a boom period, but this shortage was solved through recourse to labor from agricultural reserves. In fact, however, this was a prolonged period of economic difficulty for 
many individual employers, regardless of the fact that the economy as a whole was growing quickly.

Table 7: Openings-to-Applicants ratio

$\begin{array}{llllll}1971 & 1.19 & 1979 & 0.82 & 1987 & 0.80 \\ 1972 & 1.57 & 1980 & 0.77 & 1988 & 1.16 \\ 1973 & 2.26 & 1981 & 0.72 & 1989 & 1.39 \\ 1974 & 1.14 & 1982 & 0.59 & 1990 & 1.51 \\ 1975 & 0.65 & 1983 & 0.61 & 1991 & 1.41 \\ 1976 & 0.72 & 1984 & 0.66 & 1992 & 1.02 \\ 1977 & 0.57 & 1985 & 0.67 & 1993 & 0.70 \\ 1978 & 0.63 & 1986 & 0.61 & 1994 & 0.66\end{array}$

Source: Japan Statistical Yearbook

Official and private publications from the period abound with references to "severe" and "critical" labor shortages. In the latter half of 1967 wages began rising at a faster rate than productivity (Labor Ministry White Paper, 1970-71). According to a 1969 Labor Ministry report, ten percent of firms surveyed reported that they had had to idle part of their production facilities because they could not get enough workers (Oriental Economist, May 1969). Fifty percent of firms surveyed predicted they would not be able to get enough suitable labor in the future, and another 38\% said they would get enough labor only if they were not choosy about whom they got. Another Ministry survey later that year revealed that $80 \%$ of manufacturing enterprises reported they were unable to proceed with planned expansions simply because they could not get enough labor (Oriental Economist, August 1969).

The problems became more severe in subsequent years: a Labor Ministry White Paper from 1971-72 reported that openings for skilled workers were being filled at a rate of $19.8 \%$ and 
that the absolute number of openings was close to 2 million. Forecasts for later years were pessimistic: the Labor Ministry projected that if economic growth were to continue at an annual rate of $10 \%$ from 1970-1975, the shortfall of workers would reach 4.1 million (relative to a labor force of around 50 million (Labor White Paper 1972-73). In other words, it was not possible for the economy to continue to grow at such a rate, given population and labor force constraints. The government explicitly recognized that labor shortages would become a serious constraint on future economic growth (e.g. MITI White Paper on International Trade, 1970).

There was, at least in some parts of the government, a remarkable willingness to adjust growth rate expectations downwards because of labor supply constraints.

The [Economic and Social Development Plan, adopted March 1967, for fiscal years 1967-71] set the growth rate at about 8 per cent per annum.... The establishment of this comparatively low growth rate was due to the expectation that the labor market, particularly that for young labor, would become smaller. (Miyazaki 1970: 377)

As Miyazaki notes, Japanese economic plans have tended to underestimate real growth potential: actual growth consistently exceeded estimates in the plans. Still, the fact that the government was willing to allow perceived labor shortages to dictate reduced prospects for economic growth stands in marked contrast to the path followed by many European countries - where growth was maintained in part by importing large amounts of labor.

From one angle, perceptions of this sort mattered more than reality itself: following W.I. Thomas, we should consider that to the extent the labor shortage was perceived as real by important interest groups, then that perception was real in its consequences. The importance of Japan's labor reserves was diminished by the widely held notion that such workers were not in 
fact available or were unsuitable, whether because of age, gender, training, or location. Japanese employers resisted the ideas of extending the retirement age, retraining older workers, and employing more middle-aged women. They expressed preferences for different solutions, based on the reality they saw.

What many employers in fact wanted was that the government would allow them to import workers from abroad. The phenomenon of bringing in workers under the guise of “trainees" began during this period (Ochiai 1974), and the Labor Ministry announced plans to create an official program along these lines (though involving a mere 5000 workers), with the explicit acknowledgment that doing so would also help alleviate labor shortages (Far Eastern Economic Review, 3 October 1970). The Japanese Chamber of Commerce and Industry (representing small and medium-sized businesses) adopted a resolution in 1970 urging the government to explore the option of importing labor. Many businesses and business associations, concerned about the shortage of unskilled and semi-skilled labor, submitted reports to the government urging that the trainee program be expanded (Kuptsch and Oishi 1995). The Tokyo Chamber of Commerce and Industry called in July 1970 for an expansion of the trainee program in a document entitled "The Demand on Next Year's Labor Policy"; it also insisted that employers be able to import workers from other Asian countries independently of the trainee system (Ochiai 1974).

The government's response was not altogether negative: a section of the Economic Planning Agency announced that in 1970 that it would study the option in relation to its impact on future economic growth (Japan Economic Journal, 8 December 1970). In addition, the Economic Council, an advisory group in the Prime Minister's office, discussed the foreign worker question as it formulated a "New Economic Social Development Plan for 1970-1975" 
(Japan Economic Journal, 14 September 1971). ${ }^{3}$ And the government - in particular, the Ministry of Foreign Affairs, the Labor Ministry, and the Ministry of International Trade and Industry - sanctioned relatively small training programs for foreigners. These programs were developed in an atmosphere in which Japan was attempting (or trying to appear to attempt) to contribute to the development of poorer countries in the region. Following the sixth Asian regional conference of the International Labor Office, the Labor Ministry adopted a "Technical Development Plan" in 1971 which provided for acceptance of "technical trainees" from Asian countries. Despite official conditions specifying that such trainees must not have on-the-job training, it became clear that many companies offering the training were using their charges for cheap labor (Ochiai 1974). In the end, however, a foreign worker program of more significant dimensions did not emerge during this period.

The difficulties with labor supply found additional concrete expression in a very significant datum: the transfer of income shares from capital to labor, partly as a result of labor's enhanced bargaining position in a tight labor market. Even after the first oil shock, Japanese unions negotiated very large wage increases in 1974:

The result - coming at a time when the disruption of the oil and commodity price rises and the efforts to control inflation were putting heavy brakes on the growth in output - was not only to fuel inflation but also to maintain and even increase real wages in spite of reduced average working hours, thus effecting a sizable shift in the proportion of national income going to wages at the expense of profits. (Dore 1986, 101-2)

As is evident from Table 8, the dramatic shift in 1974 was a continuation of trends of previous years. The shift was due to in part to the recession (where profits fell faster than wages), but 
labor's share never again dropped to the level of the 1960s, nor did capital's share ever return to the level of 1970. Moreover, labor's increasing share in the national income was anticipated (e.g. Japan Labor Bulletin, September 1973, citing a Labor Ministry White Paper). That is, not only did the transfer happen, but many observers believed it would happen. It would be difficult to argue that these shifts were unrelated to the shortage of labor, though of course other factors were probably implicated as well, e.g. the 1971 "Nixon shock." Inflation, declining (relative) profits, and production bottlenecks were precisely the kinds of problems that resorting to foreign labor was designed to resolve in other countries, given labor shortages and expanding economies. Why was Japan (i.e., the Japanese government) unwilling to adopt a policy measure that had successfully accomplished these goals in other countries?

Table 8: Distribution of National Income

$\begin{array}{rrrrrr} & \begin{array}{r}\text { \% to } \\ \text { Labor }\end{array} & \begin{array}{r}\text { \% to } \\ \text { Capital }\end{array} & & \begin{array}{r}\text { \% to } \\ \text { Labor }\end{array} & \begin{array}{r}\% \text { to } \\ \text { Capital }\end{array} \\ 1970 & 54.0 & 18.3 & 1983 & 69.3 & 11.0 \\ 1971 & 58.6 & 15.2 & 1984 & 68.9 & 12.1 \\ 1972 & 57.0 & 12.6 & 1985 & 67.8 & 12.8 \\ 1973 & 58.5 & 11.7 & 1986 & 67.9 & 12.7 \\ 1974 & 62.4 & 6.5 & 1987 & 68.1 & 12.9 \\ 1975 & 65.6 & 6.0 & 1988 & 66.7 & 14.1 \\ 1976 & 65.8 & 6.0 & 1989 & 67.1 & 13.1 \\ 1977 & 66.5 & 6.3 & 1990 & 67.9 & 11.3 \\ 1978 & 66.3 & 11.3 & 1991 & 68.6 & 10.7 \\ 1979 & 66.5 & 11.5 & 1992 & 69.7 & 9.5 \\ 1980 & 66.8 & 10.8 & 1993 & 70.9 & 9.2 \\ 1981 & 68.6 & 10.1 & 1994 & 72.4 & 8.3 \\ 1982 & 69.0 & 10.8 & 1995 & 73.4 & 5.6\end{array}$

Source: computed from the Bank of Japan's Economic Statistics Annual. Capital's share refers to entrepreneurial income of private incorporated enterprises, including dividends. 


\section{Substitutes for Foreign Labor}

Before addressing that question, we need to understand what Japan did, instead of importing labor, to resolve the problem of labor shortages. We have seen that the shortage was perceived as a real problem that had to be addressed in some manner. Solutions actually advocated by the government and adopted by employers included automation and other means of increasing worker productivity and output; exporting some types of production to low-wage countries; hastening the mobilization of "reserves" labor into the urban labor force; allowing inflation to increase as labor shortages contributed to increasingly militant wage demands; and, as we have seen, allowing the transfer of income from capital to labor. Some of these changes

derived not only from the labor shortage but from other problems and goals as well. But each of them also had the effect of alleviating the labor shortage and thus diminishing the pressure for importing labor.

Productivity increases during this period were almost without parallel (with reference both to other countries and to other times in Japanese economic history). Annual rates of productivity increases averaged 11 percent from 1960 through 1970 and returned to that level in 1972 after a recession-induced dip in 1971. In 1973 productivity increased by 19.8 percent (the increase exceeded 20 percent in the manufacturing sector) (Galenson and Odaka 1976). This was a period of rapid growth in automation and robotics. Increased labor productivity meant not only that fewer workers could produce the same or greater output, but that it was possible to pay the higher wages that Japanese workers were demanding.

This was also the period in which Japanese direct foreign investment abroad began to increase significantly, partly as a result of the labor shortage (Sekiguchi 1979). The cumulative 
total of investment abroad was US\$3.6 billion in 1970 and increased by 287 percent over the next three years, to US\$10.3 billion. More than half of this investment was directed to lowwage developing countries (especially in Asia) and consisted of labor-intensive production in consumer goods industries making standardized products. In addition, almost half of the number of investments were made by small- or medium-sized firms (though clearly in terms of volume large firms accounted for a much larger proportion) (Kojima 1983). On both counts it is clear that many of the firms investing overseas were precisely the ones that were having difficulty finding workers in Japan. Moreover, the export of capital was well controlled by the Bank of Japan (and thus by the government itself).

Another way in which employers coped with the labor shortage was to mobilize domestic labor that was either employed in other firms or sectors or was not in the labor force. There was much discussion in policymaking circles about the need to increase labor mobility among firms (in part by de-emphasizing traditions of "lifetime employment" and seniority-based wage formulas - see various Labor Ministry White Papers from the period). Another much-discussed topic was the need to facilitate the continued employment of older workers, i.e., those who had been forced to "retire" at age 55. Middle-aged women were also increasingly seen as potential workers.

Finally, there is a certain sense in which we can say that an additional response to the labor shortage was to do nothing, simply to let employers suffer. Suffering, of course, took the form of wage increases, lost opportunities for expansion, and even production cutbacks - all as described above. Such cases represented opportunity costs for investors: in a situation in which more labor was available, investors would likely have made greater profits. These opportunity 
costs thus came as a direct result of government policy - the policy not to permit imported labor in large quantities.

It would grant far too much coherence to government policy-making to argue that there was a grand design here, that the government developed a comprehensive approach to labor supply problems comprising the above elements. There were many other economic policy concerns at this time, and the measures adopted had numerous purposes: Japanese investment abroad, for example, was part of a process of "internationalization" that was designed to advance foreign policy goals (Higashi and Lauter 1990). But each of those elements played a role in alleviating the labor shortage itself or its effects, such that most employers could continue to operate and make a profit even though cheap foreign labor was not available. In this sense the Japanese economy followed a qualitatively different path from most Western European economies. Moreover, this path did have a certain degree of coherence insofar as its components derived in part from the government's refusal to allow firms to import labor: from one point of view, all the above policies or choices were substitutes for foreign labor, even if they were not intended as such.

\section{Explaining the Japanese Path}

Constructing a theoretical explanation for Japan's limited use of foreign labor would involve finding a combination of factors that did not characterize the countries that did import labor under similar circumstances. This sort of comparative work would require extended discussion of other cases and will not be attempted here. I propose instead to accomplish two 
more limited goals. First, I will briefly raise questions about existing theories of international labor migration, questions that arise precisely through consideration of the Japanese case. And second, I will suggest some of the factors that were most likely to have made Japan different. Several traditional theories of labor migration, developed to explain positive cases in western countries, encounter difficulty when applied to Japan (as a negative case). If the theories presumed to explain labor migration to other destinations also invoke factors that characterize countries where numbers of migrant workers are small, then clearly something is amiss with those theories. Neoclassical theory, for example, emphasizes development gaps (especially as expressed in wage differences) between sending and (potential) receiving countries. But the disparities between Japan and many of its neighbors were at least as great as those between European "guestworker" countries and the countries that sent workers to Europe. In the end, of course, those gaps undoubtedly contributed to the initiation of migration flows from, say, Peru, Pakistan and China to Japan. But clearly development gaps alone do not explain labor migration: they must work in interaction with other factors.

Dual labor market theory (e.g. Piore 1979) does not fare any better. Here, labor migration is supposed to arise from the demands expressed by employers for foreign labor, given that citizens are unwilling to take unattractive jobs in the secondary sector of the economy. But Japan's economic dualism has been widely recognized (e.g. Pempel 1978) and is if anything more pronounced than that of many other industrial countries. Large firms are usually well insulated from seasonal and other variations in demand for their products, and the smaller firms that bear the brunt of demand variation have indeed often found it difficult to find workers at wages the firms can afford to pay. But the latter's demands for foreign workers have, especially until 
recently, gone unanswered by the government - indicating that demand for foreign labor does not automatically bring about its satisfaction ( $c f$. Weiner 1995, Lim 1992). The factors invoked by world-systems theory (e.g. Sassen 1988) also characterize Japan, which has long had (ex-) colonial relations and trade ties with many of its neighbors.

None of these theories is by any means wrong or useless - but insofar as the factors they invoke also characterize Japan, the story they present is at least incomplete. It would appear that they were developed through analysis only of countries where labor migration actually happened on a significant scale. There has been little if any systematic analysis of countries that have received only relatively small numbers of foreign workers. This methodological bias has hampered the ability of migration theory to account for variation in migration outcomes.

Theories focusing on state policy in the receiving country, however, are likely to be more helpful in distinguishing between positive and negative cases and thus in accounting for Japan's distinctive experience with foreign labor. There are convincing arguments that the liberal democratic state does in fact have the capacity to control immigration (e.g. Freeman 1992, 1994; Miller 1986, 1994; Brubaker 1994), though frequently that control is not exercised because of the constellation of domestic political interests and international political constraints (Hollifield 1992). In this context we then need to look for patterns in where, when, and why that control is used to restrict labor migration.

Weiner suggests strongly that "entry rules are only marginally shaped by economic considerations...." (1985: 443-44; see also Zolberg 1981). Receiving country governments are especially mindful of security considerations relating to immigration (Weiner 1993, Miller 1997). Labor shortages do not automatically result in labor migration: instead, "the contrasts [in national 
approaches] are due to differences in conceptions of national identity - specifically, whether a nation is built on the notion of cultural homogeneity or cultural diversity and whether the notion of pluralism extends from the political to the cultural realm" (Weiner 1995: 73-4). Weiner's argument is similar to some specific arguments concerning Japan, where xenophobic or insular culture is said to account for Japan's closure to migrant labor (see e.g. Oka 1994; Zolberg 1981; Freeman and Mo $1996^{4}$ ). The difficulty with this cultural/politics argument is apparent in at least two ways. First, in Weiner's own discussion of this point, he places Japan, Germany and Italy in the same group (contrasted with Australia) - even though Germany has imported many times more workers than Japan in spite of an arguably similar cultural disposition towards foreigners. And second, public opinion polls reveal a surprising openness to foreign labor in Japan: according to one study (cited in Mahmood 1996), only 15\% of those surveyed agreed with the proposition that the government's policy of not admitting unskilled foreign workers should be continued. Komai (1998) reports similar results from other surveys: two-thirds of respondents are said to believe that Japan should be more open to immigrants, though some forms of discrimination are also apparent. If culture in fact accounts for variation in different approaches to the foreign labor question, it must do so in a more complex way, in interaction with other factors. It is not clear that the role of political factors has been effectively specified in this particular approach.

A more promising line of inquiry investigates the relation between the state and the economy and its effect on migration policy. Zolberg (1992), for example, discerns long-term global shifts in migration policy (openness $v s$. restrictiveness) that follow changes in international economic regimes. In the post-war period, advanced economies are said to have 
confronted the same basic dilemmas concerning immigration, which led to the adoption of quite similar methods of dealing with problems such as maintaining national identity while addressing inflationary pressures (Zolberg 1991; see also Martin 1993). Zolberg also suggests that "variations of the basic pattern can be accounted for by differing national configurations, within which two elements were especially significant: the role of the state in relation to economic development and the organization of the indigenous working class at the relevant time" (1987: 61). Despite presenting a rich history of different forms of migrant labor in the modern period, however, this analysis emphasizes the overall similarities in labor migration to countries that have actually used foreign labor. I mean to advocate a similar type of argument here, though I intend it to advance the theoretical goal of distinguishing positive and negative cases, rather than explaining similarities among positive cases.

In a more fine-grained analysis of the post-war period, Freeman (1995) argues that the political structure of liberal democracies favors organized interests that benefit from open immigration policies; that same structure penalizes the typically more diffuse groups that oppose large-scale immigration. However, while most states with open immigration policies may be liberal democracies, it is not clear that all liberal democracies have open immigration policies. Freeman's explanandum here is explicit: "A single model of immigration politics accommodates fundamental features of all the receiving states" (1995: 896; emphasis added). If, however, our goal is to understand why some countries use migrant labor on a large scale while others refrain from doing so, then it is not clear that Freeman's model will allow us to account for variation on this level. In the current context, extending Freeman's argument in this way would seem to depend on classifying Japan as something other than a liberal democracy - a position that 
becomes explicit but is not explored in depth in a more recent article (Freeman and Mo 1996). Even if we were to accept the notion that Japan is different from western liberal democracies in fundamental ways, we would still have to contend with liberal countries such as Finland and Norway, where immigration has been quite limited.

A focus on state policy clearly leads in the right direction (cf. Portes 1997). The fact that there was very little foreign labor in Japan is fundamentally rooted in the state's decision not to allow employers to import workers in large numbers. We then need to explain this policy decision. The preferences of policy makers were important but not sufficient. In addition, what most likely mattered in Japan was the ability of the state to implement these preferences, especially when powerful private interests could have profited from a different policy (e.g. imported labor). We therefore need to explore some of the foundations of this capacity. I suggest that the literature on institutional structure and state policy is especially relevant here (for general works see e.g. Evans 1995, Hall 1986, Steinmo, Thelen and Longstreth 1992, Hollingsworth, Schmitter and Streeck 1994).

Economic policy in Japan has long been distinguished by the location of decisionmaking: most major decisions were made by the bureaucracies, not by the Diet (Johnson 1982, Fukui 1972, Knoke et al. 1996). This was especially true through the late 1960s and early 1970s, the period discussed in this paper. The bureaucrats generally concerned themselves less with the profitability of particular companies and more with the long-term trajectory of the economy. This approach was facilitated by long-term single party rule: the political environment was relatively stable, such that policy-makers in the bureaucracies could implement their decisions without fear that a new government would try to impose a different direction or philosophy 
(Pempel 1978, 1990). A new government would have found it difficult to impose its will on the bureaucracies in any case, as the latter are insulated to a relatively high degree from political control: political appointments to the ministries number only about two dozen, compared to the one thousand or so appointments made by US presidents. The ministries are instead staffed by cohesive, highly educated elites, chosen by a process widely seen as meritocratic, at least in comparison to some other countries (Johnson 1982). Civil servants are said to be concerned with formulating policies that "can meet a national interest test rather than a clamorous opportunity test" (Wade 1990: 373-4). Moreover, the ministries have numerous powerful tools to manipulate economic incentives such that private economic actors' behavior can be pushed in certain directions (Johnson 1982).

Business does have a central role in economic policy-making in Japan, but what matters concerning foreign labor policy is the fact that the policy-making process is open effectively mostly to big business, through its powerful peak associations' representation on the various government-sponsored economic councils. Small business, to a greater degree excluded from this part of the process, bears the costs associated with many decisions (Pempel 1978). Small businesses were much harder hit by the labor shortage in the late 1960s and early 1970s. Big business could better afford to pay higher wages to keep its labor rolls filled and had a variety of means of ensuring labor market flexibility (Taira 1970); small business was squeezed and would have benefited greatly from access to cheap foreign labor but was unable to translate its demands into policy. Small business, then, had no alternative but to hire workers that were not considered desirable (women, older workers) and to invest in increasing productivity (Nakamura 1995). 
These claims concerning the Japanese state are contested (for critiques, see e.g. Samuels 1987, Friedman 1988, Richardson 1997). But they seem to fit well with the fact that the Japanese government refrained from adopting a significant guestworker program in spite of employer demands to do so. An important piece of the explanation for Japan's autarkic approach to labor policy, then, likely consists of its mode of economic governance. In particular, those who stood to benefit most from imported labor were systematically excluded from policy making.

By 1975 , economic recession had essentially brought an end to the (perception of) labor shortages: there was an abundance of labor at least until the mid-1980s (Nakamura 1995), and so the question of foreign labor effectively disappeared from the political agenda for over a decade. By the late 1980s, however, the mode of economic governance in Japan had evolved to the extent that the bureaucracy's ability to resist demands for importing labor had perhaps been somewhat diminished. The locus of decision-making was shifting: as early as 1972, politicians began gaining in influence at the expense of the bureaucracies (Johnson 1989, Murumatsu and Krauss 1987, Calder 1988). This shift is at least consistent with the fact that the government began to open a "side door" to foreign workers (Sellek 1997). On the other hand, the government continued to encourage steps that reduce the demand for low-end foreign labor, such as foreign relocation of some firms and mobilization of inactive segments of the population (Mori 1997). Foreign labor, though increasing, remained a much smaller percentage of the Japanese labor force relative to other advanced capitalist countries. 


\section{Conclusion}

These latter remarks, however, are intended mainly as ideas for exploration, not as a proper theoretical explanation. The main general claim of this paper is that developing a theoretical explanation for international labor migration would require careful comparative historical work that includes discussion of positive and negative cases together, in the same framework. Migration scholars may benefit from paying more explicit attention to the question of variation in migration outcomes, so that theories distinguish between positive and negative cases. For the concept of negative cases to be useful, it has to be shown that it can be applied in a non-trivial way. This paper has shown that Japan's non-use of foreign labor in the early 1970s is usefully conceived as a negative case, because existing labor migration theory would lead us to expect that the country would have used significant numbers of foreign workers at that time.

If Japan were unique in this respect, the implications for theory might be perceived as limited. It is quite possible, however, that the notion of negative cases is useful for describing other countries' experience as well. Foreign labor continues to form a very low percentage of the labor force in Denmark, Finland, South Korea, Norway, and Ireland; in Spain and Italy, the numbers have become significant only in the last decade (OECD-SOPEMI 1995; Freeman and Mo 1996). It would be very interesting to investigate systematically whether any of these countries are negative cases as that term has been used in this paper: i.e., existing migration theory would lead us to expect a different outcome. The value of the concept will then be measured by the extent to which such a question leads to new theoretical insights. 


\section{References}

Böhning, W.R.

1984 Studies in International Labor Migration, London, Macmillan.

Boltho, A.

1975 Japan: An Economic Survey, 1953-1973, Oxford, Oxford University Press.

Brubaker, W. R.

1994 "Are Immigration Control Efforts Really Failing?" in Wayne Cornelius, Philip

Martin, and James Hollifield, eds., Controlling Immigration: A Global Perspective, Stanford, Stanford University Press.

Calder, K. E.

1988 Crisis and compensation: public policy and political stability in Japan, 1949-1986.

Princeton, Princeton University Press.

Cook, A.

1978 The Working Mother: A Survey of Problems and Programs in Nine Countries, 2nd ed., Ithaca, New York State School of Industrial and Labor Relations, Cornell University.

Cornelius, W.

1994 "Japan: The Illusion of Immigration Control," in Wayne Cornelius, Philip Martin, and James Hollifield, eds., Controlling Immigration: A Global Perspective, Stanford, Stanford University Press.

Descloitres, R.

1967 The foreign worker: adaptation to industrial work and urban life. Paris: OECD. Dore, R.

1986 Flexible Rigidities: Industrial Policy and Structural Adjustment in the Japanese Economy 1970-80, Stanford, Stanford University Press.

Emigh, R. J.

1997 "The Power of Negative Thinking: The Use of Negative Case Methodology in the Development of Sociological Theory", Theory and Society, 26: 649-84.

Evans, R., Jr.

1971 The Labor Economies of Japan and the United States, New York, Praeger Publishers. Foote, D. H.

1993 "Japan's 'Foreign Workers' Policy: A View from the US", Georgetown Immigration Law Journal, 7(4), 707-46.

Freeman, G. P.

1992 "Migration Policy and Politics in the Receiving States," International Migration Review, 26:4, 1144-67.

1994 "Can Liberal States Control Unwanted Migration?" Annals of the American Academy of Political and Social Scientists, No. 534, 17-30. 
1995 "Modes of Immigration Politics in Liberal Democratic States," International Migration Review, 29 (4), 881-902. , and Jongryn Mo

1996 "Japan and the Asian NICs as New Countries of Destination", in P.J. Lloyd and Lynne S. Williams, eds., International Trade and Migration in the APEC Region, New York, Oxford University Press.

Friedman, D.

1988 The Misunderstood Miracle: Industrial Development and Political Change in Japan, Ithaca, Cornell University Press.

Fukui, H.

1972 "Economic Planning in Postwar Japan: A Case Study in Policy Making," Asian Survey, 12:4, 327-48.

Galenson, W., with K. Odaka

1976 "The Japanese Labor Market," in Hugh Patrick and Henry Rosovsky, eds., Asia's New Giant: How the Japanese Economy Works, Washington DC, The Brookings Institution.

Hammar, T., and K. Tamas

1997 "Why do people go or stay?" in International migration, immobility, and development, edited by Tomas Hammar, Grete Brochmann, Kristof Tamas, and Thomas Faist. New York: Berg.

Herbert, U.

1990 A History of Foreign Labor in Germany, 1880-1980: Seasonal Workers, Forced Laborers, Guest Workers, trans. William Templer, Ann Arbor, University of Michigan Press.

Hicks, G.

1997 Japan's hidden apartheid: The Korean minority and the Japanese. Aldershot: Ashgate.

Higashi, C., and G. P. Lauter

1990 The Internationalization of the Japanese Economy, Second Edition, Boston, Kluwer Academic Publishers.

Hollifield, J. F.

1992 Immigrants, Markets, and States: The Political Economy of Postwar Europe, Iguchi, Y.

1998 "What We Can Learn from the German Experiences with Foreign Labor", in Myron Weiner and Tadashi Hanami, eds. Temporary Workers or Foreign Citizens? Japanese and U.S. Migration Policies, New York, New York University Press.

Japan. Ministry of Justice. Study Group on Immigration Statistics

1990 Japan and the development of international migration (Wagakuni wo meguru kokusai jinryu no hensen), Tokyo, Ministry of Justice. 
Johnson, C.

1982 MITI and the Japanese Miracle: The Growth of Industrial Policy, 1925-1975, Stanford, Stanford University Press.

1989 "MITI, MPT, and the Telecom Wars: How Japan Makes Policy for High Technology," in Chalmers Johnson, Laura D'Andrea Tyson, and John Zysman, eds., Politics and Productivity: The Real Story of Why Japan Works, New York, Ballinger.

Kamerman, S.

1979 "Work and Family in Industrialized Societies," Signs, 4, 632-50.

Knoke, D., et al.

1996 Comparing Policy Networks: Labor Politics in the U.S., Germany, and Japan, Cambridge, Cambridge University Press.

Kojima, K.

1983 "Japanese Direct Foreign Investment in Asian Developing Countries," in Gianni Fodella, ed., Japan's Economy in a Comparative Perspective, Tenterden Kent, Paul Norbury Publications Limited.

Komai, $\mathrm{H}$.

1995 Migrant Workers in Japan, trans. Jens Wilkinson, New York, Kegan Paul.

1998 "Migrants in Japan", paper presented to the Technical Symposium on International Migration and Development, The Hague, July.

Kuptsch, C., and N. Oishi

1995 German and Japanese Schemes for Workers from Transition Economies or Developing Countries, International Migration Papers, Geneva, International Labor Office.

Lie, J.

1997 “The 'problem' of foreign workers in contemporary Japan.” in The other Japan: conflict, compromise, and resistance since 1945, edited by Joe Moore. London: M.E. Sharpe.

Lim, L. L.

1990. "International labour movements: a perspective on economic exchanges and flows." in Immigration reconsidered: history, sociology, and politics, edited by Virginia YansMcLaughlin. New York: Oxford University Press.

Mahmood, R. A.

1996 "Labor Crunch, Foreign Workers and Policy Responses: The Experience of Japan," International Migration, 34(1): 97-116.

Martin, P. L.

1991 "Labor Migration in Asia: Conference Report", International Migration Review, 25(1), 176-93.

1993 "European and Asian Perspectives on Immigration Policy", in Lydio Tomasi, ed., In Defense of the Alien, Vol. 15, New York, Center for Migration Studies. 
Miller, M. J.

1986 "Policy Ad-Hocracy: The Paucity of Coordinated Perspectives and Policies," Annals of the American Academy of Political and Social Science, No. 485, May.

1994 "Towards Understanding State Capacity to Prevent Unwanted Migration: Employer Sanctions Enforcement in France, 1975-1990", in Martin Baldwin-Edwards and Martin A. Schain, eds., The Politics of Immigration in Western Europe, Ilford, Frank Cass.

1997 “International Migration and Security: Towards Transatlantic Convergence?” in Emek M. Uçarer and Donald J. Puchala, eds., Immigration Into Western Societies: Problems and Policies, London, Pinter.

Miyazaki, I.

1970 "Economic Planning in Postwar Japan," The Developing Economies, 8:4, 369-85.

Moore, B., Jr.

1966 The Social Origins of Dictatorship and Democracy: Lord and Peasant in the Making of the Modern World, Boston, Beacon Press.

Mori, H.

1997 Immigration Policy and Foreign Workers in Japan, New York, St. Martin's Press. Murumatsu, M., and E. S. Krauss

1987 "The Conservative Policy Line and the Development of Patterned Pluralism", in Kozo Yamamura and Yasukichi Yasuba, eds., The Political Economy of Japan, Vol. 1: The Domestic Transformation, Stanford, Stanford University Press.

Nagayama, T.

1992 "Clandestine Migrant Workers in Japan," Asian and Pacific Migration Journal, 1:3-4, 623-36.

1996 "Foreign Workers Recruiting Policies in Japan", Asian and Pacific Migration Journal, 5(2-3), 241-64.

Nakamura, T.

1991 "Labor Market and Manpower Policy, 1945-1985", in Kazutoshi Koshiro, ed., Employment Security and Labor Market Flexibility: An International Perspective, Detroit, Wayne State University Press.

1995 The Postwar Japanese Economy: Its Development and Structure, 1937-1994, Tokyo, University of Tokyo Press.

Ochiai, E.

1974 Ajiajin Rodoryoko Yunyu (The Importation of Asian Labor Power), Tokyo, Gendai Hyoronsha.

Oka, T.

1994 Prying Open the Door: Foreign Workers in Japan, Contemporary Issues Paper \#2, Washington, Carnegie Endowment. 
Okunishi, Y.

1996 "Labor Contracting in International Migration: The Japanese Case and Implications for Asia", Asian and Pacific Migration Journal, 5(2-3), 219-40.

OECD

1995 SOPEMI: Trends in International Migration, Paris, Organization for Economic Cooperation and Development.

Pempel, T. J.

1978 "Japanese Foreign Economic Policy: The Domestic Bases for International Behavior," in Peter Katzenstein, ed., Between Power and Plenty: Foreign Economic Policies of Advanced Industrial States, Madison, University of Wisconsin Press.

1982 Politics and Polity in Japan: Creative Conservatism, Philadelphia, Temple University Press. , ed.

1990 Uncommon Democracies: The One-Party Dominant Regimes, Ithaca, Cornell University Press.

Piore, M. J.

1979 Birds of Passage: Migrant Labor and Industrial Societies, Cambridge, Cambridge University Press, 1979.

Portes, A.

1997 "Immigration Theory for a New Century: Some Problems and Opportunities", International Migration Review, 31(4) 799-825.

Reubens, E. P.

1981 "Low-Level Work in Japan Without Foreign Workers," International Migration Review, 15: 4, 749-57.

Richardson, B. M.

1997 Japanese Democracy: Power, Coordination, and Performance, New Haven, Yale University Press.

Samuels, R. J.

1987 The Business of the Japanese State: Energy Markets in Comparative and Historical Perspective, Ithaca, Cornell University Press.

Sassen, S.

1988 The Mobility of Labor \& Capital: A Study in International Investment and Labor Flow, Cambridge, Cambridge University Press.

1993 "Economic Internationalization: The New Migration in Japan and the United States", International Migration, 31(1), 73-99.

Sekiguchi, S.

1979 Japanese Direct Foreign Investment, Montclair NJ, Allanheld, Osmun \& Co. Publishers. 
Sellek, Y.

1994 "Illegal Foreign Migrant Workers in Japan: Change and Challenge in Japanese Society," in Judith M. Brown and Rosemary Foot, eds., Migration: The Asian Experience, New York, St. Martin's Press.

1997 "Nikkeijin: The Phenomenon of Return Migration," in Michael Weiner, ed., Japan's Minorities: The Illusion of Homogeneity, New York, Routledge. , and Michael A. Weiner

1992 "Migrant Workers: The Japanese Case in International Perspective," in Glenn D. Hook and Michael A. Weiner, eds., The Internationalization of Japan, New York, Routledge.

Shimada, H.

1994 Japan's "Guest Workers": Issues and Public Policies, trans. Roger Northridge, Tokyo, University of Tokyo Press.

Taira, K.

1970 Economic Development and the Labor Market in Japan, New York, Columbia University Press.

Utsumi, A.

1988 "Will the Japanese government open the legal door?" AMPO Japan-Asia Quarterly Review 19:12-21.

Wade, $\mathrm{R}$.

1990 Governing the Market: Economic Theory and the Role of Government in East Asian Industrialization, Princeton, Princeton University Press.

Weiner, $\mathrm{M}$.

1985 "On International Migration and International Relations," Population and Development Review, 11:3, 441-55. , ed.

1993 International Migration and Security, Boulder, Westview Press.

1995 The Global Migration Crisis: Challenges to States and to Human Rights, New York, HarperCollins College Publishers.

Yamanaka, K.

1993 "New Immigration Policy and Unskilled Foreign Workers in Japan", Pacific Affairs, 66(1), 72-90.

1994 "Theory versus Reality in Japanese Immigration Policy", in Wayne Cornelius, Philip Martin, and James Hollifield, eds., Controlling Immigration: A Global Perspective, Stanford, Stanford University Press.

Zolberg, A. R.

1981 "International Migrations in Political Perspective," in Mary Kritz, Charles Keely \& Silvano Tomasi, eds., Global Trends in Migration: Theory and Research on International Population Movements, New York, Center for Migration Studies. 
1987 "Wanted But Not Welcome: Alien Labor in Western Development," in Population in an Interacting World, William Alonso, ed., Cambridge, MA, Harvard University Press.

1991 "Bounded States in a Global Market: The Uses of International Labor Migration," in Pierre Bourdieu \& James S. Coleman, eds., Social Theory for a Changing Society, Boulder CO, Westview Press/Russell Sage Foundation.

1992 "Labour Migration and International Economic Regimes: Bretton Woods and After", in Mary M. Kritz, Lin Lean Lim, and Hania Zlotnik, eds., International Migration Systems: A Global Approach, Oxford, Clarendon Press. 


\section{Notes}

${ }^{1}$ Before World War II, of course, Japan forcibly imported millions of workers from countries in the region. After the war, however, most of these workers returned to their country of origin (Oka 1994).

${ }^{2}$ A research assistant who explored the literature in Japanese supported this assertion, though I do not make a strong claim to the effect that we conducted an exhaustive search of the Japanese literature.

${ }^{3}$ These sources refute a source cited by Cornelius (1994) who asserted that the Japanese government simply never considered importing labor at this time.

${ }^{4}$ The latter, however, carefully suggest that cultural factors might be at work but that confirming this idea would require much more extensive investigation of attitudes. 